\title{
Implementasi Peraturan Gubernur Jawa Timur No. 27 Tahun 2016 Tentang Tarif Angkutan Penumpang pada Dinas Perhubungan Propinsi Jawa Timur
}

\author{
Ignatius Adiwidjaja \\ Program Studi Administrasi Publik, Universitas Tribhuwana Tunggadewi \\ ignatius.adiwidjaja@yahoo.co.id
}

\begin{abstract}
Public transportation is a problem that is always faced by the government in various regions in this country, especially areas that have a bustling city atmosphere due to overcrowding and high intensity of the community followed by mismatching the number of modes of public transportation and the imbalance of the size of roads inter-city in the province which has a structure and activity of the population is already classified as very high. East Java provincial government policy regulations contained in East Java Governor Regulation No. 27 of 2016. Transportation Agency as an implementor, conducts socialization to the community, and provides facilities as a support in the transportation system in East Java. In this study we used a qualitative method that produced a description (description) of matters relating to what was studied. Qualitative itself is a form of words rather than a row of numbers. Descriptive method approach can be interpreted as problem solving by describing or describing the state of the subject or object of research, both the behavior of individuals, community groups, institutions and so forth.
\end{abstract}

Keywords: Implementation, Public Services, Public transportation

\begin{abstract}
Abstrak. Transportasi dan angkutan umum merupakan suatu persoalan yang selalu dihadapi oleh pemerintah di berbagai daerah di tanah air ini, terutama daerah yang memiliki suasana kota yang yang ramai karena padatnya penduduk serta tingginya intensitas masyarakatnya diikuti dengan tidak sesuainya jumlah moda transportasi umum serta belum seimbangnya luas ruas jalan antar kota dalam propinsi yang mempunyai struktur serta aktifitas penduduk sudah tergolong sagat tinggi. Regulasi kebijakan pemerintah propinsi Jawa Timur yang tertuang dalam Peraturan Gubernur Jawa Timur No. 27 Tahun 2016. Dinas perhubungan sebagai implementor, melakukan sosialisasi kepada masyarakat, serta menyediakan sarana sebagai pendukung dalam system transportasi di Jawa Timur.Dalam penelitian ini kami menggunakan metode kualitatif yang menghasilkan gambaran (deskripsi) mengenai hal-hal yang berkaitan dengan apa yang diteliti. Kualitatif sendiri merupakan wujud kata-kata dari pada deretan angka-angka.Pendekatan metode deskriptif dapat diartikan sebagai pemecahan masalah dengan menggambarkan atau melukiskan keadaan subjek atau objek penelitian, baik perilaku individu, kelompok masyarakat, lembaga-lembaga dan lain-lain sebagainya.
\end{abstract}

Kata kunci: Angkutan Umum, Implementasi, Pelayanan Publik,

\section{PENDAHULUAN}

Angkutan umum adalah kendaraan atau angkutan yang memang disediakan dan dapat dipergunakan oleh masyarakat umum dengan dikenakan tarif tertentu.Kendaraan atau angkutan umum dapat berupa mobil penumpang, bus kecil, bus sedang, dan bus besar(Ahmad Munawar,2005). Keberadaan angkutan umum penumpang memiliki tujuan utama yaitu mengadakanpelayanan angkutan yang layak dan baikbagi masyarakatumum. Kriteria pelayanan yang baik ialahpelayanan yang cepat, murah, aman dan nyaman. Dengan adanyaangkutan umumini jugaakanmembuka lapangan kerja. Dilihat dari faktor lalu lintas, angkutan umum penumpang dapat mengurangi volume lalu lintas kendaraan pribadi, hal ini 
JISIP: Jurnal Ilmu Sosial dan Ilmu Politik

ISSN. 2442-6962

Vol. 10. No. 1 (2021)

dikarenakanangkutan umum penumpang merupakanangkutan massal sehingga biaya angkut dapat dibebankan kepada lebih banyak orang atau penumpang. Penumpang yang banyak menyebabkan biaya penumpang dapat ditekan serendah mungkin (Warpani,1990).

Pada era otonomi daerah sekarang ini, setiap daerah berupaya untuk memberikan pelayanan yang berkulitas di segala sector kehidupan seperti pendidikan, kesehatan, pelayanan kependudukan hingga pelayanan bidang transportasi umum.Bidang transportasi umum di Propinsi Jawa Timur melalui Peraturan Gubernur maka Dinas Perhubungan menetapkan triff untuk semua jenis kendaraan sebagai moda transportasi. Penetapan tariff dasartentu dihitung berdasarkan jarak tempuh antar terminal disemua trayek dan tujuan berdasarkan tariff dasar batas atas dan batas. Bawah pada masing-masing ukuran bus seperti bus yang berukuran 9 meter maka sebesar Rp. 128 pnp/km, selanjutnya bus dengan ukuran panjang lebih dari 9 meter sebesar Rp. 117 pnp/km. tariff jarak angkutan umum penumpang antar kota dalam propinsi kelas ekonomi bus umum yang panjangnya maksimal 9 meter batas atas sebesar Rp. 167/ $\mathrm{km}$ setiap penumpang dan batas bawah Rp. 103/km setiap penumpang. Untuk bus yang panjang lebih dari sebesar Rp. 152/km per penumpang untuk batas atasnya dan batas bawahnya Rp.94/km/penumpang sudah termasuk premi asuransi jasa rahaja sebesar Rp. 60,00 (enam puluh rupiah)

Namun dalam praktiknya, banyak ditemui masalah yang bertentangan dengan Peraturan Gubernur tersebut.Pelanggaran tersebut di antaranya adalah sebagai berikut : sopir angkutan umum yang menaikkan harga angkutan secara sepihak, memaksa penumpang dengan pembayaran tarif angkutan umum sesuai dengan kehendak sopir angkutan umum, hingga memanfaatkan ketidaktahuan masyarakat mengenai tarif angkutan umum, dan masih banyak masalah lainnya yang membuat masyarakat merasa tidak nyaman menggunakan jasa angkutan umum Kota di Jawa Timur. Terkait dengan permasalahan tersebut maka dapat kami analisis masalahnya;Bagaimana peran dinas perhubungan dalam mengimplementasi peraturan Gubernur No. 27 Tahun 2016 Tentang Tarif angkutan kelas ekonomi di Propinsi Jawa Timur.

Beberapa teori yang bisa kamigunakan dalam mendukung analisis adalah; Poerwadarminta (1995:751) Peranan adalah Tindakan yang dilakukan seseorang atau sekelompok orang dalam suatu peristiwa. Sedankan Soekanto dalam Larasati, D., \& Kurrahman, Y. (2019) Peranan adalah sebuah proses yang dinamisdari suatu kedudukan (status). Jadi apabila seseorang melaksanakan sustu tugas yang berhubungan tugas pokok dan kewajibannya sesuai dengankedudukannyadalam suatu bagian atau unit dari satuankerja, berarti orng tersebut sudah mempunya peranan atau telah berperan.Selain teori mengenai peran, teori implementasi juga dapat digunakan. Dalam hal ini Implementasi diartikan sebagai sebuah tindakan atau pelaksanaan dari sebuah rencana yang sudah disusun secara matang dan terperinci.

Implementasi kebijakan pada prinsipnya adalah cara agar sebuah kebijakan dapat mencapai tujuannya. Tidak lebih dan tidak kurang.Oleh karenanya pemerintah selalu melakukan tindakan yang rasional untuk mencapai perubahan, baik besar maupun kecil. Hakekat utama implementasi adalah memahami apa yang seharusnya terjadi sesudah suatu program dinyatakan berlakuatau dirumuskan. Implementasi berarti menyediakan sarana untuk melaksanakan suatu kebijakan dan dapat menimbulkan dampak terhadap sesuatu hal. Dalam pelaksanaannya menuntut sesuatu hal (Jones); adanya orang atau pelaksana dan kemampuan organisasional yang sering disebut resource. Dalam hal ini implementasi proses penerimaan sumberdaya tambahan sehingga dapat menghitung apa yang harus dikerjakan. Rangkaian implementasi kebijakan dapat diamati dengan jelas yaitu dimulai dari program, ke proyek dan ke kegiatan.Kebijakan diturunkan berupa program kemudian diturunkan menjadi proyek-proyek, dan 
JISIP: Jurnal Ilmu Sosial dan Ilmu Politik

ISSN. 2442-6962

Vol. 10. No. 1 (2021)

akhirnya berwujud pada kegiatan-kegiatan, baik yang dilakukan oleh pemerintah, masyarakat maupun kerjasama pemerintah dengan masyarakat.

\section{METODE PENELITIAN.}

Metode yang digunakan dalam penelitian ini adalah metode penelitian kulaitatif, dengan desain pendekatannya menggunakan pendekatan deskriptif.Pendekatan deskriptif dapat dipahami sebagai prosedur untuk memecahkan masalah yang diteliti baik perilaku individu, kelompok masyarakat, atau lemabaga tertentu pada saat sekarang atau berdasarkan fakta yang ada dilapangan.Peneliti mengambil data pada Dinas Perhubungan Propinsi Jawa Timur dengan menggunakan teknik penentuan informan dalam penelitian ini adalah purposive sampling. Memfocuskan pada fenomena utama tentang peran Dinas perhubungan dalam Mengimplementasikan PERGUB Jawa Timur No. 27/2016.Dengan lokasi penelitiannyadi Dinas Perhubungan Propinsi Jawa Timur.Informan yang diwawancarai meliputi pegawai dinas perhubungan/ sector wilayah,kasi lalulintas, para sopir angkot, dan pengguna angkutan umum. Pengumpulan datanya menggunakan Observasi; dalam hal ini peneliti mengarah pada perilaku individu, lembaga, kelompok masyarakat, actor pemerintah, swasta serta melihat sejauh mana perilaku pelayanan terhadap para pengguna jasa.Wawancara; peneliti melakukan wawancara mendalam dengan informan dan partisipan yang benar-benar memahami persoalan pelayanan dan tariff angkutan umum (pegawai Dinas Perhubungan, kepala sector wilayah, kasi lalulintas, sopir serta penumpang). Dokumentasi; peneliti juga mengumpulkandata dari dokumen-dokumen pendukung seperti PRGUB No. 27/2016, keterangan tariff dan trayek antar kota.

\section{PEMBAHASAN}

Angkutan umum merupakan salah satu transportasi di Propinsi Jawa Timur yang banyak digunakan dalam mendukung aktivitas masyarakat yang ada, baik aktivitas akademik, ekonomi dan sosial serta aktivitas lainnya. Angkutan umum ini menjadi pilihan untuk mengatasi meningkatnya kebutuhan masyarakat akan transportasi.Dinas Perhubungan Jawa Timur adalah Organisasi Perangkat Daerah (OPD) yang memiliki tugas memberikan layanan transportasi kepada masyarakat. Hal ini juga didukung dengan Visi dan Misi Dinas Perhubungan Propinsi Jawa Timur adalah "Mewujudkan Pelayanan Transportasi Yang Berkualitas Untuk Mendukung Pembangunan dan Perekonomian Daerah" Dan Misi: 1).Meningkatkan pelayanan yang murah, mudah, aman, nyaman, dan cepat serta pemerataan pelayanan transportasi dengan prioritas pada Wilayah Kepulauan dan masyarakat berpenghasilan rendah. 2). Meningkatkan peranan Transportasi dalam percepatan dan pemerataan pembangunan dan perekonomian daerah serta Mendorong partisipasi masyarakat dan dunia usaha dalam meningkatkan pelayanan perhubungan.

Dalam rangka merealisasikan tujuan dan sasaran yang ditetapkan oleh Dinas Perhubungan maka Dinas Perhubungan Propinsi Jawa Timur berpedoman terhadap Peraturan Gubernur tentang Tarif Angkutan Umum. Di dalam Peraturan Gubernur dijelaskan bahwa Dinas Perhubungan mempunyai peranan penting sebagai Dinas yang menangani bidang transportasi secara umum. Berdasarkan hasil penelitian, bahwa peran Dinas Perhubungan Propinsi Jawa Timur adalah sebagai berikut:

\section{Sebagai Pembuat Kebijakan}

Dalam implementasi Peraturan Gubernur yang ada, Dinas Perhubungan melakukan perannya yaitu dengan membuat kebijakan, diantaranya adalah menetapkan beberapa aturan turunan sebagai aturan pelaksana di lapangan, meliputi: 1) Menetapkan jalur trayek angkutan antar kota dalam propinsi, di mana 
JISIP: Jurnal Ilmu Sosial dan Ilmu Politik

ISSN. 2442-6962

Vol. 10. No. 1 (2021)

terdapat 130 jalur trayek angkutan kota yang tersebar di seluruh wilayah Propinsi Jawa Timur. 2) Melakukan penetapan tarif, dimana tarif ini berhubungan dengan tarif yang dikenakan untuk penumpang angkutan umum yaitu:

\section{Tabel . Trayek dan tariff angkutan Kota Dalam Propinsi di Jawa Timur}

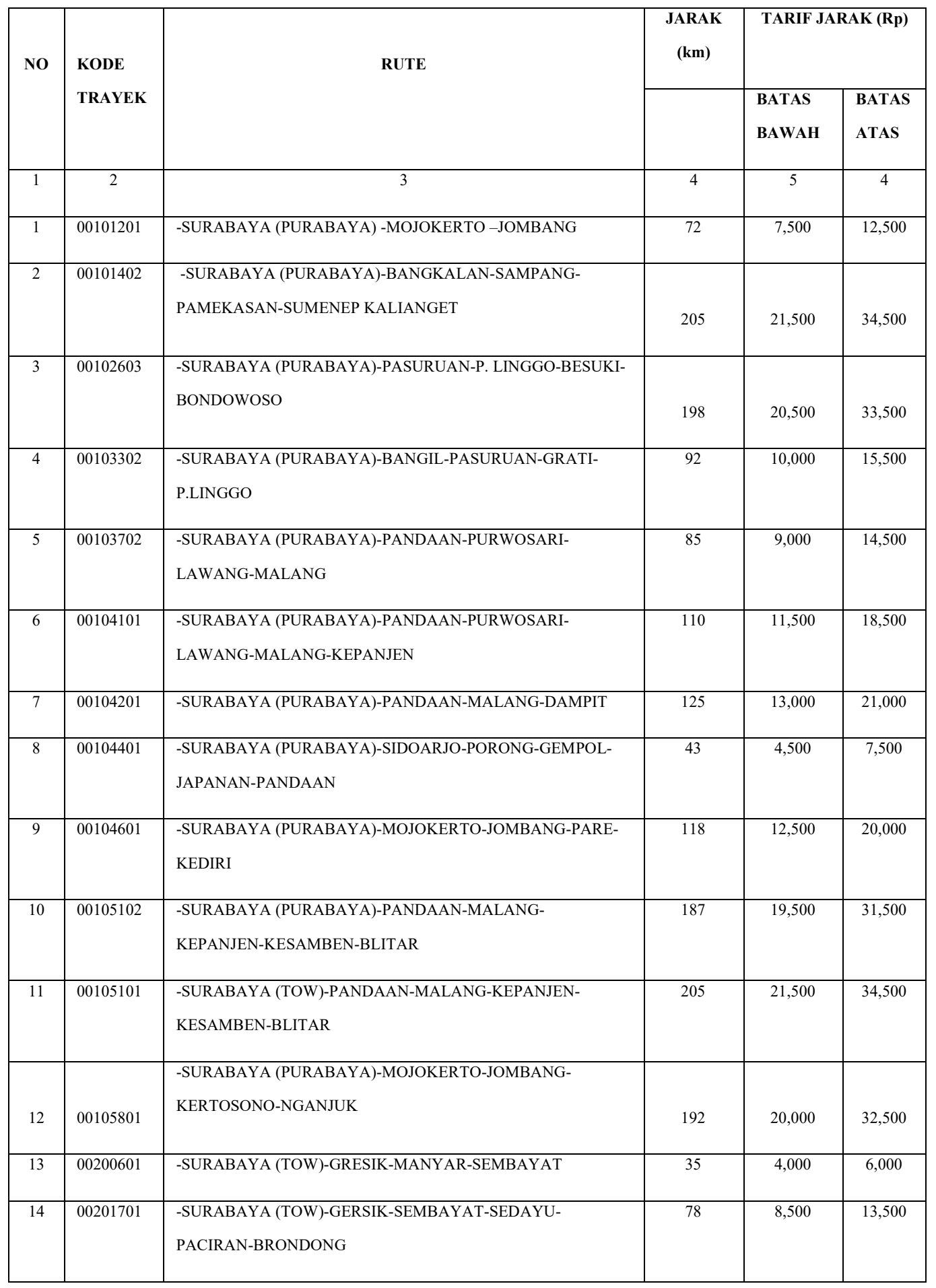

www.publikasi.unitri.ac.id 
JISIP: Jurnal Ilmu Sosial dan Ilmu Politik

ISSN. 2442-6962

Vol. 10. No. 1 (2021)

\begin{tabular}{|c|c|c|c|c|c|}
\hline 15 & 00106601 & $\begin{array}{l}\text {-SURABAYA (PURUBAYA)-GRESIK-LAMONGAN-BABAT- } \\
\text { PAKAH-TUBAN }\end{array}$ & 134 & 14,000 & 22,500 \\
\hline 16 & 00206602 & $\begin{array}{l}\text {-SURABAYA (TOW)-GRESIK-LAMONGAN-BABAT-PAKAH- } \\
\text { TUBAN }\end{array}$ & 116 & 12,500 & 19,500 \\
\hline 17 & 00106801 & $\begin{array}{l}\text {-SURABAYA (PURUBAYA)-GRESIK-LAMONGAN-BABAT- } \\
\text { SUMBEREJO-BOJONEGORO }\end{array}$ & 133 & 14,000 & 22,500 \\
\hline 18 & 00206802 & $\begin{array}{l}\text {-SURABAYA (TOW)-GRESIK-LAMONGAN-BABAT- } \\
\text { SUMBEREJO-BOJONEGORO }\end{array}$ & 115 & 12,000 & 19,500 \\
\hline 19 & 00401101 & -JOYOBOYO-KRIAN-MOJOKERTO & 49 & 5,500 & 8,500 \\
\hline 20 & 01001601 & -KAMAL-BANGKALAN-T.MERAH-SAMPANG-PAMEKASAN & 114 & 12,000 & 19,500 \\
\hline 21 & 01104301 & -MOJOKERTO-PASURUAN & 67 & 7,000 & 11,500 \\
\hline 22 & 01204601 & $\begin{array}{l}\text {-JOMBANG-JATIPALEM-SEMBUNG-PERAK-MENGKRENG- } \\
\text { KERTOSONO-BARON-WARUJAYENG-SONOAGENG- } \\
\text { MRICAN-KEDIRI }\end{array}$ & 59 & 6,500 & 10,000 \\
\hline 23 & 01206601 & -JOMBANG-PLOSO-NGIMBANG-BABAT-TUBAN & 105 & 11,000 & 18,000 \\
\hline 24 & 01206801 & -JOMBANG-PLOSO-NGIMBANG-BABAT-BOJONEGORO & 103 & 11,000 & 17,500 \\
\hline 25 & 01302401 & $\begin{array}{l}\text {-SUMENEP-PAMEKASAN-SAMPANG-BANGKALAN-KAMAL- } \\
\text { SURABAYA (PURABAYA)-PASURUAN-P.LINGGO-BESUKI- } \\
\text { SITUBONDO-B.WANGI-MUNCAR }\end{array}$ & 518 & 53,500 & 87,000 \\
\hline 26 & 01303101 & $\begin{array}{l}\text {-SUMENEP-PAMEKASAN-SAMPANG-T.MERAH- } \\
\text { BANGKALAN-KAMAL-SURABAYA (PURABAYA)- } \\
\text { PASURUAN-P.LINGGO-KAMAL-SURABAYA (PURABAYA)- } \\
\text { PASURUAN-P.LINGGO }\end{array}$ & 286 & 30,000 & 48,000 \\
\hline 27 & 01303701 & $\begin{array}{l}\text {-SUMENEP-PAMEKASAN-SAMPANG-BANGKALAN- } \\
\text { SURABAYA (PURABAYA)-PANDAAN-MALANG }\end{array}$ & 279 & 29,000 & 47,000 \\
\hline 27 & 01401901 & $\begin{array}{l}\text {-KALIANGET-SUMENEP-PAMEKASAN-SAMPANG- } \\
\text { BANGKALAN-KAMAL-SURABAYA (PURABAYA)- } \\
\text { PASURUAN-P.LINGGO-BESUKI-SITUBONDO-B.WANGI }\end{array}$ & 495 & 51,500 & 83,000 \\
\hline
\end{tabular}

www.publikasi.unitri.ac.id 
JISIP: Jurnal Ilmu Sosial dan Ilmu Politik

ISSN. 2442-6962

Vol. 10. No. 1 (2021)

\begin{tabular}{|c|c|c|c|c|c|}
\hline 28 & 01800102 & $\begin{array}{l}\text {-BANYUWANGI-GENTENG-JEMBER-BALONG-KENCONG- } \\
\text { LUMAJANG-WONOREJO-KLAKAH-P.LINGGO-PASURUAN- } \\
\text { BANGIL-SURABAYA (PURABAYA) }\end{array}$ & 331 & 34,500 & 55,500 \\
\hline 29 & 01801401 & $\begin{array}{l}\text {-BANYUWANGI-GENTENG-JEMBER-WONOREJO-P.LINGGO- } \\
\text { PASURUAN-SURABAYA (PURABAYA)-BANGKALAN- } \\
\text { SAMPANG }\end{array}$ & 512 & 53,000 & 86,000 \\
\hline 30 & 01803101 & -BANYUWANGI-GENTENG-JEMBER & 120 & 12,500 & 20,500 \\
\hline 31 & 01804701 & $\begin{array}{l}\text {-BANYUWANGI-GENTENG-JEMBER-WONOREJO-P.LINGGO- } \\
\text { PASURUAN-MALANG-KEPANJEN-SELOREJO-BLITAR- } \\
\text { T.AGUNG-TR.NGGALEK }\end{array}$ & 489 & 50,500 & 82,000 \\
\hline 32 & 01805101 & $\begin{array}{l}\text {-BANYUWANGI-GENTENG-JEMBER-WONOREJO-P.LINGGO- } \\
\text { PASURUAN-PURWOSARI-MALANG-KEPANJEN-SELOREJO- } \\
\text { WLINGI-BLITAR }\end{array}$ & 407 & 42,000 & 68,500 \\
\hline 33 & 01806401 & $\begin{array}{l}\text {-BANYUWANGI-JEMBER-WONOREJO-P.LINGGO- } \\
\text { PASURUAN-SURABAYA (PURABAYA)-MOJOKERTO- } \\
\text { JOMBANG-KERTOSONO-NGANJUK-SURABAYA } \\
\text { (PURABAYA)-MOJOKERTO-JOMBANG-KERTOSONO- } \\
\text { NGANJUK }\end{array}$ & 503 & 52,000 & 84,500 \\
\hline 34 & 02401401 & $\begin{array}{l}\text {-MUNCAR-BANYUWANGI-SITUBONDO-BESUKI-P.LINGGO- } \\
\text { PASURUAN-SURABAYA (PURABAYA)-BANGKALAN- } \\
\text { SAMPANG }\end{array}$ & 529 & 55,000 & 88,500 \\
\hline 35 & 02402701 & -MUNCAR-BANYUWANGI-SITUBONDO & 122 & 13,000 & 20,500 \\
\hline 36 & 02502701 & $\begin{array}{l}\text {-KALIPAHIT-BENCULUK-BANYUWANGI-ASEMBAGUS- } \\
\text { SITUBONDO }\end{array}$ & 154 & 16,000 & 26,000 \\
\hline & & -BONDOWOSO-BESUKI-KRAKSAN-P.LINGGO-PASURUAN- & & & \\
\hline
\end{tabular}

www.publikasi.unitri.ac.id 
JISIP: Jurnal Ilmu Sosial dan Ilmu Politik

ISSN. 2442-6962

Vol. 10. No. 1 (2021)

\begin{tabular}{|c|c|c|c|c|c|}
\hline 37 & 02601401 & $\begin{array}{l}\text { SURABAYA (PURABAYA)-BANGKALAN-BLEGA-SAMPANG- } \\
\text { PAMEKASAN-SUMENEP-KALIANGET }\end{array}$ & 403 & 42,000 & 67,500 \\
\hline 38 & 02702201 & $\begin{array}{l}\text {-SITUBONDO-ASEMBAGUS-BANYUWANGI-ROGOJAMPI- } \\
\text { BENCULUK-PS.GARAN }\end{array}$ & 167 & 17,500 & 28,000 \\
\hline 39 & 03101401 & $\begin{array}{l}\text {-JEMBER-TANGGUL-WONOREJO-PB.LINGGO-PASURUAN- } \\
\text { SURABAYA (PURABAYA)-BANGKALAN-SAMPANG- } \\
\text { PAMEKASAN-SUMENEP-KALIANGET }\end{array}$ & 395 & 41,000 & 66,500 \\
\hline 40 & 03101403 & $\begin{array}{l}\text {-JEMBER-AMBULU-KENCONG-LUMAJANG-P.LINGGO- } \\
\text { PASURUAN-SURABAYA (PURABAYA)-BANGKALAN- } \\
\text { SAMPANG-PAMEKASAN-SUMENEP-KALIANGET }\end{array}$ & 432 & 45,000 & 72,500 \\
\hline 41 & 03103801 & $\begin{array}{l}\text {-JEMBER-RAMBIPUJI-BALUNG-KENCONG-LUMAJANG- } \\
\text { DAMPIT-MALANG }\end{array}$ & 196 & 20,500 & 33,000 \\
\hline 42 & 03103802 & $\begin{array}{l}\text {-JEMBER-AMBULU-BALUNG-KENCONG-LUMAJANG- } \\
\text { DAMPIT-MALANG }\end{array}$ & 211 & 22,000 & 35,500 \\
\hline 42 & 03106601 & $\begin{array}{l}\text {-JEMBER-TANGGUL-WONOREJO-P.LINGGO-PASURUAN- } \\
\text { SURABAYA (PURABAYA)-GRESIK-LAMONGAN-BABAT- } \\
\text { TUBAN }\end{array}$ & 321 & 33,500 & 54,000 \\
\hline 44 & 03106602 & $\begin{array}{l}\text {-JEMBER-BALUNG-KENCONG-LUMAJANG-WONOREJO- } \\
\text { PB.LINGGO-PASURUAN-BANGIL-SURABAYA (PURABAYA)- } \\
\text { LAMONGAN }\end{array}$ & 361 & 37,500 & 60,500 \\
\hline 45 & 03106801 & $\begin{array}{l}\text {-JEMBER-TANGGUL-WONOREJO-P.LINGGO-PASURUAN- } \\
\text { SURABAYA (PURABAYA)-GRESIK-LAMONGAN-BABAT- } \\
\text { BOJONEGORO }\end{array}$ & 319 & 33,000 & 53,500 \\
\hline 46 & 03106802 & $\begin{array}{l}\text {-JEMBER-BALUNG-KENCONG-LUMAJANG-WONOREJO- } \\
\text { PB.LINGGO-PASURUAN-BANGIL-SURABAYA (PURABAYA)- } \\
\text { LAMONGAN-BABAT-BOJONEGORO }\end{array}$ & 343 & 35,500 & 57,500 \\
\hline 47 & 03107201 & $\begin{array}{l}\text {-JEMBER-TANGGUL-WONOREJO-PB.LINGGO-PASURUAN- } \\
\text { SURABAYA (PURABAYA)-BANGKALAN-SAMPANG- } \\
\text { PAMEKASAN-SUMENEP-PASEA }\end{array}$ & 419 & 43,500 & 70,500 \\
\hline 48 & 03202701 & $\begin{array}{l}\text {-JEMBER-ARJASA-MAESAN-BONDOWOSO-WONOSARI- } \\
\text { PRAJEKAN-SITUBONDO }\end{array}$ & 73 & 8,000 & 12,500 \\
\hline
\end{tabular}

www.publikasi.unitri.ac.id 
JISIP: Jurnal Ilmu Sosial dan Ilmu Politik

ISSN. 2442-6962

Vol. 10. No. 1 (2021)

\begin{tabular}{|c|c|c|c|c|c|}
\hline 49 & 03202702 & $\begin{array}{l}\text {-JEMBER-ARJASA-MAESAN-BONDOWOSO-PRAJEKAN- } \\
\text { SITUBONDO-PANARUKAN-JANGKAR }\end{array}$ & 116 & 12,500 & 19,500 \\
\hline 50 & 03301301 & -P.LINGGO-GRATI-PASURUAN-BANGIL & 286 & 30,000 & 48,000 \\
\hline 51 & 03301303 & $\begin{array}{l}\text {-P.LINGGO-GRATI-PASURUAN-BANGIL-SURABAYA } \\
\text { (TOW)KAMAL-BANGKALAN-BLEGA-SAMPANG- } \\
\text { PAMEKASAN-SUMENEP }\end{array}$ & 301 & 31,500 & 50,500 \\
\hline 52 & 03301601 & $\begin{array}{l}\text {-P.LINGGO-GRATI-PASURUAN-BANGIL-SURABAYA } \\
\text { (PURABAYA)-KAMAL-BANGKALAN-BLEGA-SAMPANG- } \\
\text { PAMEKASAN }\end{array}$ & 226 & 23,500 & 38,000 \\
\hline 53 & 03301801 & $\begin{array}{l}\text {-P.LINGGO-KLAKAH-WONOREJO-LUMAJANG-KENCONG- } \\
\text { BALUNG-JEMBER-MRAWAN-GENTENG-BANYUWANGI }\end{array}$ & 239 & 25,000 & 40,000 \\
\hline 54 & 03301802 & $\begin{array}{l}\text {-P.LINGGO-KLAKAH-WONOREJO-TANGGUL-JEMBER- } \\
\text { MRAWAN-GENTENG-BANYUWANGI }\end{array}$ & 215 & 22,500 & 36,000 \\
\hline 55 & 03301901 & $\begin{array}{l}\text {-P.LINGGO-KRAKSAAN-BESUKI-PANARUKAN- } \\
\text { SITUBONDO-ASEMBAGUS-BAJULMATI-BANYUWANGI }\end{array}$ & 198 & 20,500 & 33,500 \\
\hline 56 & 03302401 & $\begin{array}{l}\text {-P.LINGGO-KRAKSAAN-BESUKI-PANARUKAN- } \\
\text { SITUBONDO-ASEMBAGUS-BAJULMATI-BANYUWANGI- } \\
\text { ROGOJAMPI-MUNCAR }\end{array}$ & 235 & 24,500 & 39,500 \\
\hline 57 & 03302701 & $\begin{array}{l}\text {-P.LINGGO-KLAKAH-WONOREJO-LUMAJANG-KENCONG- } \\
\text { BALUNG-JEMBER-ARJASA-BONDOWOSO-SITUBONDO }\end{array}$ & 193 & 20,000 & 32,500 \\
\hline 58 & 03303101 & -P.LINGGO-KLAKAH-WONOREJO-TANGGUL-JEMBER & 96 & 10,000 & 16,500 \\
\hline 59 & 03303102 & $\begin{array}{l}\text {-P.LINGGO-KLAKAH-WONOREJO-LUMAJANG-KENCONG- } \\
\text { BALUNG-JEMBER }\end{array}$ & 120 & 12,500 & 20,500 \\
\hline 60 & 03303501 & -P.LINGGO-BREMI & 52 & 5,500 & 9,000 \\
\hline 61 & 03303801 & $\begin{array}{l}\text {-MALANG-TUREN-DAMPIT-TIRTOMOYO-CANDIPURO- } \\
\text { LUMAJANG-WONOREJO-P.LINGGO }\end{array}$ & 172 & 18,000 & 29,000 \\
\hline 62 & 03304701 & -P.LINGGO-GRATI-PASURUAN-BANGIL-TRENGGALEK & 288 & 30,000 & 48,500 \\
\hline 63 & 03306401 & -P.LINGGO-PASURUAN & 283 & 29,500 & 47,500 \\
\hline 64 & 03306402 & $\begin{array}{l}\text {-P.LINGGO-GRATI-PASURUAN-BANGIL-MOJOSARI- } \\
\text { MOJOKERTO-JOMBANG-KERTOSONO-NGANJUK- } \\
\text { CARUBAN-MADIUN-PONOROGO }\end{array}$ & 252 & 24,000 & 38,500 \\
\hline 65 & 03307101 & -P. LINGGO-SUKAPURA-NGADISARI & 43 & 4,500 & 7,000 \\
\hline 66 & 03701801 & -MALANG-PURWOSARI-PASURUAN-GRATI-PB.LINGGO & 310 & 29,500 & 47,500 \\
\hline
\end{tabular}

www.publikasi.unitri.ac.id 
JISIP: Jurnal Ilmu Sosial dan Ilmu Politik

ISSN. 2442-6962

Vol. 10. No. 1 (2021)

\begin{tabular}{|c|c|c|c|c|c|}
\hline 67 & 03701901 & $\begin{array}{l}\text {-MALANG-PURWOSARI-PASURUAN-PB.LINGGO- } \\
\text { KRAKSAAN-BESUKI-PANARUKAN-SITUBONDO- } \\
\text { ASEMBAGUS-BANYUWANGI }\end{array}$ & 297 & 28,000 & 45,500 \\
\hline 68 & 03702601 & $\begin{array}{l}\text {-MALANG-PURWOSARI-PASURUAN-GRATI-P.LINGGO- } \\
\text { KRAKSAAN-BESUKI-PANARUKAN-SITUBONDO- } \\
\text { BONDOWOSO }\end{array}$ & 231 & 22,000 & 35,500 \\
\hline 69 & 03702602 & $\begin{array}{l}\text {-MALANG-PURWOSARI-PASURUAN-GRATI-P.LINGGO- } \\
\text { WONOREJO-TANGGUL-JEMBER-ARJASA-BONDOWOSO }\end{array}$ & 239 & 23,000 & 36,500 \\
\hline 70 & 03703101 & $\begin{array}{l}\text {-MALANG-PURWOSARI-PASURUAN-GRATI-PB.LINGGO- } \\
\text { WONOREJO-TANGGUL-JEMBER }\end{array}$ & 195 & 18,500 & 30,000 \\
\hline 71 & 03703102 & $\begin{array}{l}\text { MALANG-PURWOSARI-PASURUAN-GRATI-PB.LINGGO- } \\
\text { WONOREJO-LUMAJANG-KENCONG-BALUNG-JEMBER }\end{array}$ & 218 & 21,000 & 33,500 \\
\hline 72 & 03703301 & -MALANG-PURWOSARI-PASURUAN-GRATI-PB.LINGGO & 99 & 9,500 & 15,500 \\
\hline 73 & 03705201 & $\begin{array}{l}\text {-MALANG-PANDAAN-SURABAYA (PURABAYA)- } \\
\text { MOJOKERTO-JOMBANG-KERTOSONO-NGANJUK-MADIUN }\end{array}$ & 246 & 23,500 & 37,500 \\
\hline 73 & 03705801 & $\begin{array}{l}\text {-MALANG-PANDAAN-SURABAYA (PURABAYA)- } \\
\text { MOJOKERTO-JOMBANG }\end{array}$ & 273 & 26,000 & 42,000 \\
\hline 75 & 03706601 & $\begin{array}{l}\text {-MALANG-PANDAAN-SURABAYA (PURABAYA)-GRESIK- } \\
\text { LAMONGAN-BABAT-TUBAN }\end{array}$ & 201 & 19,000 & 31,000 \\
\hline 76 & 03706801 & $\begin{array}{l}\text {-MALANG-PANDAAN-SURABAYA (PURABAYA)-GRESIK- } \\
\text { LAMONGAN-BABAT-BOJONEGORO }\end{array}$ & 199 & 19,000 & 30,500 \\
\hline 77 & 03804201 & -MALANG-TUREN-DAMPIT & 40 & 4,000 & 6,500 \\
\hline 78 & 03804701 & $\begin{array}{l}\text {-MALANG-KEPANJEN-SELOREJO-WLINGI-BLITAR- } \\
\text { NGUNUT-T.AGUNG-DURENAN-T. GALEK }\end{array}$ & 163 & 15,500 & 25,000 \\
\hline 79 & 03805001 & $\begin{array}{l}\text {-MALANG-KEPANJEN-SELOREJO-WLINGI-BLITAR- } \\
\text { NGUNUT-T.AGUNG }\end{array}$ & 131 & 12,500 & 20,000 \\
\hline 80 & 03805102 & -MALANG-KEPANJEN-SELOREJO-WLINGI-BLITAR & 90 & 9,000 & 14,000 \\
\hline 81 & 03807001 & $\begin{array}{l}\text {-MALANG-TUREN-DAMPIT-CANDIPURO-LUMAJANG- } \\
\text { WONOREJO-LUMAJANG-KENCONG-BALUNG-AMBULU }\end{array}$ & 204 & 19,500 & 31,500 \\
\hline 82 & 03807301 & -MALANG-DAMPIT-CANDIPURO-LUMAJANG & 130 & 12,500 & 20,000 \\
\hline 83 & 03901201 & -MALANG-BATU-KADEMANGAN-JOMBANG & 99 & 9,500 & 15,500 \\
\hline 84 & 03904601 & -MALANG-BATU-KANDANGAN-PARE-KEDIRI & 119 & 11,500 & 18,500 \\
\hline
\end{tabular}

www.publikasi.unitri.ac.id 
JISIP: Jurnal Ilmu Sosial dan Ilmu Politik

ISSN. 2442-6962

Vol. 10. No. 1 (2021)

\begin{tabular}{|c|c|c|c|c|c|}
\hline 85 & 04101301 & $\begin{array}{l}\text {-KEPANJEN-MALANG-PURWOSARI-PANDAAN-SURABAYA } \\
\text { (PURABAYA)-BANGKALAN-SAMPANG-PAMEKASAN - } \\
\text { SUMENEP }\end{array}$ & 304 & 29,000 & 46,500 \\
\hline 86 & 04103101 & $\begin{array}{l}\text {-KEPANJEN-MALANG-PURWOSARI-PASURUAN-GRATI- } \\
\text { PB.LINGGO-WONOREJO-TANGGUL-JEMBER }\end{array}$ & 215 & 20,500 & 33,000 \\
\hline 87 & 04103102 & $\begin{array}{l}\text {-KEPANJEN-MALANG-PURWOSARI-PASURUAN-GRATI- } \\
\text { PB.LINGGO-WONOREJO-LUMAJANG-KENCONG-BALUNG- } \\
\text { JEMBER }\end{array}$ & 239 & 23,000 & 36,500 \\
\hline 88 & 04107201 & $\begin{array}{l}\text {-KEPANJEN-MALANG-PURWOSARI-PANDAAN-SURABAYA } \\
\text { (PURABAYA)-BANGKALAN-SAMPANG-PAMEKASAN- } \\
\text { SUMENEP-PASEAN }\end{array}$ & 330 & 31,500 & 50,500 \\
\hline 89 & 04304501 & -PASURUAN-TRETES & 48 & 5,000 & 7,500 \\
\hline 90 & 04604801 & -KEDIRI-GRINGGING-NGANJUK & 45 & 4,500 & 7,000 \\
\hline 91 & 04605101 & -KEDIRI-SRENGAT-BLITAR & 61 & 6,000 & 9,500 \\
\hline 92 & 04606401 & $\begin{array}{l}\text {-KEDIRI-KERAS-TL.AGUNG-DURENAN-T.GALEK- } \\
\text { PONOROGO }\end{array}$ & 121 & 11,500 & 18,500 \\
\hline 93 & 04606601 & -KEDIRI-PARE-JOMBANG-NGIMBANG-BABAT-TUBAN & 151 & 14,500 & 23,500 \\
\hline 94 & 04704801 & -T.GALEK-T.AGUNG-KEDIRI-NGANJUK & 111 & 10,500 & 17,000 \\
\hline 95 & 04705101 & -T.GALEK-DURENAN-T.AGUNG-NGUNUT-BLITAR & 73 & 7,000 & 11,500 \\
\hline 96 & 04705601 & -T.GALEK-LOROK & 87 & 8,500 & 13,500 \\
\hline 97 & 04706601 & $\begin{array}{l}\text {-T.GALEK-DURENAN-T.AGUNG-KERAS-KEDIRI-PARE- } \\
\text { JOMBANG-NGIMBANG-BABAT-TUBAN }\end{array}$ & 217 & 20,500 & 33,500 \\
\hline 98 & 04706602 & $\begin{array}{l}\text {-T.GALEK-DURENAN-T.AGUNG-KERAS-KEDIRI- } \\
\text { KERTOSONO-JOMBANG-NGIMBANG-BABAT-TUBAN }\end{array}$ & 225 & 21,500 & 34,500 \\
\hline 99 & 04806801 & $\begin{array}{l}\text {-NGANJUK-REJOSO-BETEK-TEMAYANG-DANDER- } \\
\text { RAJEKWESI }\end{array}$ & 66 & 6,500 & 10,500 \\
\hline 100 & 05001901 & $\begin{array}{l}\text {-TL.AGUNG-BLITAR-KEPANJEN-MALANG-PURWOSARI- } \\
\text { PASURUAN-PB.LINGGO-KRAKSAAN-BESUKI-SITUBONDO- } \\
\text { ASEMBAGUS-BANYUWANGI }\end{array}$ & 428 & 40,500 & 65,500 \\
\hline 101 & 05003101 & $\begin{array}{l}\text {-T.AGUNG-NGUNUT-BLITAR-KEPANJEN-MALANG- } \\
\text { PURWOSARI-PASURUAN-GRATI-PB.LINGGO-WONOREJO- } \\
\text { TANGGUL-JEMBER }\end{array}$ & 327 & 31,000 & 50,000 \\
\hline 102 & 05004602 & -T.AGUNG-NGUNUT-BLITAR-SRENGAT-KEDIRI & 102 & 10,000 & 16,000 \\
\hline
\end{tabular}

www.publikasi.unitri.ac.id 
JISIP: Jurnal Ilmu Sosial dan Ilmu Politik

ISSN. 2442-6962

Vol. 10. No. 1 (2021)

\begin{tabular}{|c|c|c|c|c|c|}
\hline 103 & 05004801 & -T.AGUNG-KERAS-KEDIRI-GRINGGING-NGANJUK & 79 & 7,500 & 12,500 \\
\hline 133 & 05004802 & $\begin{array}{l}\text {-T.AGUNG-NGUNUT-BLITAR-SRENGAT-KEDIRI- } \\
\text { GRINGGING-NGANJUK }\end{array}$ & 147 & 14,000 & 22,500 \\
\hline 104 & 05005102 & -T.AGUNG-KERAS-KEDIRI-SRENGAT-BLITAR & 95 & 9,000 & 15,000 \\
\hline 105 & 05006402 & $\begin{array}{l}\text {-T.AGUNG-NGUNUT-BLITAR-SRENGAT-KEDIRI- } \\
\text { GRINGGING-NGANJUK-CARUBAN-MADIUN-DOLOPO- } \\
\text { PONOROGO }\end{array}$ & 227 & 21,500 & 35,000 \\
\hline 106 & 05104701 & -BLITAR-T.AGUNG-T.GALEK & 73 & 7,000 & 11,500 \\
\hline 107 & 05104801 & -BLITAR-SRENGAT-KEDIRI-KEDUNGSARI-NGANJUK & 106 & 10,500 & 16,500 \\
\hline 108 & 05205801 & -MADIUN-MAOSPATI-MAGETAN & 27 & 3,000 & 4,500 \\
\hline 109 & 05206001 & -MADIUN-MAOSPATI-NGAWI & 34 & 3,500 & 5,500 \\
\hline 110 & 05206401 & -MADIUN-DOLOPO-PONOROGO & 30 & 3,000 & 5,000 \\
\hline 111 & 05206801 & -MADIUN-NGAWI-PADANGAN-BOJONEGORO & 105 & 10,000 & 16,500 \\
\hline 112 & 05406401 & $\begin{array}{l}\text {-PONOROGO-BALONG-SLAHUNG-GEMAKREJO- } \\
\text { TEGALOMBO-MANGUNARJO-ARJOSARI-PACITAN }\end{array}$ & 79 & 7,500 & 12,500 \\
\hline 113 & 06005301 & -NGAWI-CARUBAN & 38 & 4,000 & 6,000 \\
\hline 114 & 06006601 & -NGAWI-PADANGAN-BOJONEGORO-TUBAN & 128 & 12,500 & 20,000 \\
\hline 115 & 06006801 & -NGAWI-NGRAHO-PADANGAN-BOJONEGORO & 82 & 8,000 & 13,000 \\
\hline 116 & 06403901 & $\begin{array}{l}\text {-PONOROGO-DOLOPO-MADIUN-CARUBAN-NGANJUK- } \\
\text { GRINGGING-KEDIRI-PARE-BATU-MALANG }\end{array}$ & 244 & 23,000 & 37,500 \\
\hline 117 & 06404701 & -PONOROGO-DENGOK-TAMANSARI-TUGU-T. GALEK & 55 & 5,500 & 8,500 \\
\hline 118 & 06405101 & $\begin{array}{l}\text {-PONOROGO-T.GALEK-DURENAN-T.AGUNG-NGUNUT- } \\
\text { BLITAR }\end{array}$ & 128 & 12,500 & 20,000 \\
\hline 119 & 06406801 & -BOJONEGORO-JATIROGO & 48 & 5,000 & 7,500 \\
\hline 120 & 06603901 & $\begin{array}{l}\text {-TUBAN-BABAT-NGIMBANG-JOMBANG-KANDANGAN- } \\
\text { BATU-MALANG }\end{array}$ & 204 & 19,500 & 31,500 \\
\hline 121 & 06606401 & -TUBAN-RENGEL-BOJONEGORO-JATIROGO & 105 & 10,000 & 16,500 \\
\hline 122 & 06606802 & -TUBAN-T.BOYO-J.ROGO-PARENGAN-BOJONEGORO & 107 & 10,500 & 16,500 \\
\hline 123 & 06606803 & -TUBAN-JATIROGO-BOJONEGORO & 107 & 10,500 & 16,500 \\
\hline 124 & 06806601 & -BOJONEGORO-RENGEL-TUBAN & 57 & 5,500 & 9,000 \\
\hline
\end{tabular}

www.publikasi.unitri.ac.id 
JISIP: Jurnal Ilmu Sosial dan Ilmu Politik

ISSN. 2442-6962

Vol. 10. No. 1 (2021)

\begin{tabular}{|c|c|c|c|c|c|}
\hline 125 & 07001301 & $\begin{array}{l}\text {-AMBULU-BALUNG-KENCONG-WONOREJO-PB.LINGGO- } \\
\text { PASURUAN-BANGIL-SURABAYA (PURABAYA)- } \\
\text { BANGKALAN-SAMPANG-PAMEKASAN-SUMENEP }\end{array}$ & 400 & 38,000 & 61,000 \\
\hline 126 & 07003701 & $\begin{array}{l}\text {-AMBULU-BALUNG-KENCONG-WONOREJO-KLAKAH- } \\
\text { P.LINGGO-GRATI-PASURUAN-PURWOSARI-MALANG }\end{array}$ & 214 & 20,500 & 33,000 \\
\hline 127 & 07004701 & $\begin{array}{l}\text {-AMBULU-BALUNG-KENCONG-WONOREJO-P.LINGGO- } \\
\text { PASURUAN-PURWOSARI-MALANG-SELOREJO-BLITAR- } \\
\text { TL.AGUNG-TRENGGALEK }\end{array}$ & 379 & 36,000 & 58,000 \\
\hline 128 & 07006401 & $\begin{array}{l}\text {-AMBULU-KENCONG-WONOREJO-P.LINGGO-PASURUAN- } \\
\text { BANGIL-MOJOSARI-MOJOKERTO-JOMBANG-NGANJUK- } \\
\text { MADIUN-PONOROGO }\end{array}$ & 366 & 34,500 & 56,000 \\
\hline 129 & 07301801 & $\begin{array}{l}\text {-WONOREJO-KLAKAH-PB.LINGGO-PASURUAN-BANGIL- } \\
\text { SURABAYA (PURABAYA)-BANGKALAN-SAMPANG- } \\
\text { PAMEKASAN }\end{array}$ & 266 & 25,500 & 40,500 \\
\hline 130 & 07303101 & -WONOREJO-LUMAJANG-KENCONG-BALUNG-JEMBER & 78 & 7,500 & 12,000 \\
\hline
\end{tabular}

Sumber: Dinas Perhubungan Propinsi Jawa Timur, 2020

\section{Melakukan Sosialisasi Terhadap Masyarakat}

Supaya implementasi Peraturan Gubernur No. 27 Tahun 2016mengenai tarif angkutan dapat berjalan dengan baik dan dapat diterima oleh semua lapisan masyarakat Dishub Propinsi Jawa Timur melalui Bidang Angkutan terus bersosialisasi kepada seluruh lapisan masyarakat. Salah satunya dengan rutin membagikan stiker tarif yang nantinya di tempel di pintu angkutan umum. Dengan begitu, masyarakat bisa mengetahui berapa tarif resmi yang diberlakukan.

\section{Fasilitas Penunjang Pelayanan Transportasi Umum}

Dinas Perhubungan juga berperan dalam menyediakan fasilitas penunjang pelayanan angkutan umum meliputi: Unit-unit angkutan kota, menyediakan sarana dan prasarana seperti halnya terminal, posko pengaduan. Posko pengaduan biasanya didirikan di depan kantor dinas perhubungan dan juga bisa di kantor polisi terdekat. Hal ini dilakukan agar memudahkan masyarakat jika ada warga yang hendak melakukan pengaduan adanya pelanggaran oleh oknum sopir terhadap tarif yang dikenakan oleh pengemudi angkutan umum kepada penumpang

\section{Melakukan pengawasan dan kerjasama dengan instansi lainnya.}

Dinas Perhubungan Propinsi Jawa Timurbekerjasama dengan instansi lainnya untuk memperlancar implementasi Peraturan Gubernur No. 27 Tahun 2016 tersebut.Dalam hal ini, Dinas perhubungan bekerja sama dengan TNI dan POLRI. Apabila ditemukan ada sopir yang melakukan pelanggaran terhadap tarif angkutan umum maka korban bisa 
melaporkan oknum tersebut. Dan Oknum sopir tersebut akan diproses dan harus membuat surat pernyataan. Tindakan memaksa penumpang membayar tidak sesuai tarif merupakan tindakan kriminal.

\section{Melakukan Pembinaan Terhadap Sopir Angkutan Umum.}

Selain melakukan pengawasan, Dinas Perhubungan juga melakukan pembinaan terhadap para sopir angkutan umum berupa sosialisasi secara periodik, yang biasanya dilakukan 3 bulan sekali. Sosialisasi ini sebagai penegasan mengenai Pergub. No. 27/2016 yang berhubungan dengan angkutan umum.

\section{KESIMPULAN}

Dari hasil penelitian diatas maka dapat kami simpulkan bahwa Peran Dinas Perhubungan dalam menmplementasi Peraturan Gubernur Jawa Timur No. 27 Tahun 2016 Tentang Tarif Angkutan Umum sudah sesuai dengan petunjuk pelaksanaan pada Peraturan Gubernur yang menjadi landasan utamanya. Hal ini dilihat dari tariff yang dikenakan pada setiap penumpang berdasarkan jarak (PNP-KM), adalah jumlah tempat duduk-km, dihitung dengan mengalikan jumlah tempat duduk yang tersedia dengan frekwensi serta jarak tempuh dari tempat asal ke tempat tujuan. Sesuai dengan perannya maka bersama tim melakukan Pengawasan dan Pembinaan terhadap sopir angkutan umum, serta masyarakat luas agar meningkatkan kesadaran dalam menggunakan fasilitas public secara baik dan benar.

\section{DAFTAR PUSTAKA}

Creswell, W. Jhn, 2010.Research Design: Pendekatan Kualitatif, Kuantitatif dan Mixed (Edisi Ketiga) di terjemahkan oleh Ahmad Fawaid. Pustaka Pelajar

Dwiyanto, A., dkk. 2007. Kinerja Tata Pemerintah Daera Di Indonesia. Yogyakarta: PSKK UGM.

Dwiyanto, A.,2011. Pembagiaan Urusan Pemerinta: Inkonsistensi Regulasi, Distro Implementasi, dan Implikasihnya Terhadap Pelaksanaan Otonomi Daera, Input Paper Untuk DSF, World Bank.

Hessel Nogi S. Tangkilisan, M.Si, Drs, 2003. Kebijakan Publik yang Membumi, Konsep, Strategi dan Kasus, Yogyakarta: Lukman Offset dan YPAPI.

Liahati, Larasati DC, 2018. Implementasi Program Keluarga Harapan (PKH) dalam Upaya Penanggulangan Kemiskinan di Kelurahan Sisir Kecamatan Batu Kota Batu. JISIP,Vol.7,No.2dikutipdari

:https://publikasi.unitri.ac.id/index.php/fisip/article/view/1426/1001

Larasati, D., \& Kurrahman, Y. (2019).Peran Pemerintah Desa dalam Mengelola Wisata Hutan Pinus untuk Meningkatkan Pendapatan Asli Desa di Desa Bendosari, Kecamatan Pujon, Kabupaten Malang. REFORMASI, 9(2), 161-167. doi:http://dx.doi.org/10.33366/rfr.v9i2.1509

Miles, Matthew B \& A Michael Huberman.1992. Analisi Data Kualitatif.Diterjemahkan oleh Tjejep Rohendi Rohidi. Jakarta: UIP 
JISIP: Jurnal Ilmu Sosial dan Ilmu Politik

ISSN. 2442-6962

Vol. 10. No. 1 (2021)

Peraturan Gubernur No. 27Tahun 2016 Tentang Tarif Angkutan

Setiawan, Guntur. 2004. Implementasi Dalam Birokrasi Pembangunan. Bandung:Remaja Rosdakarya Offset.

Sugiyono, 2014, Metode Penelitian Kualitatif, Kuantitatif Dan R Dan D, Bandung, Alfabeta.

Wahab, Solichin, 2008.Analisis Kebijakan Dari Formulasi ke Implementasi Kebijakan Negara (Edisi kedua). Bumi Aksara

Widodo, Joko. 2013. Analisis Kebijakan Publik; Konsep Dan Aplikasi Analisis Proses Kebijakan Publik (Cetakan ke - Sembilan). Malang: Bayu Media Publishing 